\title{
COMMENTS
}

\section{Mitigating Punishment for Statutory Rape}

\author{
Britton Guerrina $\dagger$
}

Vladimir Nabokov's Lolita is the story of an illegal relationship between an adult, Humbert, and a twelve year old girl, Lolita. In his defense, Humbert does not deny having had a sexual relationship with Lolita, but instead pleads that "it was she who seduced me."

Humbert's claim that Lolita initiated their sexual relationship has a familiar ring; it is a defense frequently asserted by adult men charged with statutory rape. ${ }^{2}$ These men claim that the young female's initiation of the relationship exonerates them entirely of guilt; alternatively, they contend-like Humbert-that such conduct at least renders them less culpable. ${ }^{3}$ While the defendant rarely wins an acquittal by using this defense, the defense may convince a judge or jury to reduce his punishment. ${ }^{4}$

\footnotetext{
$\dagger$ B.A./M.A. 1990, The University of Chicago; J.D. Candidate 1999, The University of Chicago.

1 Vladimir Nabokov, Lolita 131 (Vintage 1997). Some psychologists have found that adolescents and prepubescent children can be "openly seductive" and can even initiate sexual contact with adults. C.K Li, D.J. West, and T.P. Woodhouse, Children's Sexual Encounters with Adults 160-61 (Duckworth 1990) (discussing research projects studying sexual deviancy).

2 Statutory rape is "unlawful sexual intercourse with a female under the age of consent ... [who] is conclusively presumed to be incapable of consent by reason of her tender age." Black's Law Dictionary 1412 (West 6th ed 1990). While statutory rape laws protect both children and adolescents, this Comment will focus primarily on adolescent females. Similarly, although many age-of-consent laws prohibit sexual activity between consenting adolescents, this Comment will address only the case of adult-adolescent sexual relations.

${ }^{3}$ For a striking example of an underage girl seducing an older man, see State $v$ Nice, 103 Idaho 89, 645 P2d 323, 324 (1982).

‘ See State v Rush, 24 Kan App 2d 113, 942 P2d 55, 57 (1997) (admitting victim's pro-
} 
The courts' consideration of the sexual aggression of the "victim" is part of a broader effort to create some flexibility in the application of strict liability statutory rape laws. Courts inject this flexibility by mitigating the punishment of statutory rape defendants when they perceive the sentence to be out of alignment with the defendant's actual culpability. Victim conduct often serves as a convenient proxy or signal for the defendant's level of culpability. In addition, many state legislatures have responded more formally to this lack of flexibility by enacting graduated scales of permissible and impermissible adolescent sexual behavior, ${ }^{5}$ as opposed to the traditional bright line rule that sets the age of consent relatively high and strictly prohibits sexual intercourse with a person below that age. ${ }^{6}$ Even in states that have enacted such graduated statutory schemes, however, courts continue to use victim conduct to mitigate a male defendant's punishment. Because conduct of varying degrees of culpability may fall within a particular segment of the graduated scheme, mitigation enables courts to align defendants' punishment with their perceived culpability, as measured against community moral standards.

This Comment argues that it is inappropriate for courts to consider victim conduct when determining the appropriate level of punishment for statutory rape defendants. Victim conduct is a poor indicator of defendant culpability. It often does not indicate that the young female was capable of making an informed decision to have sex or that her decision was not coerced. Considering victim conduct in making punishment decisions inappropriately focuses attention on the propriety of the female victim's conduct rather than on the culpability of the defendant. For these reasons, this Comment proposes that state legislatures set a low presumptive punishment for statutory rape. They should then

vocative behavior at sentencing); Nice, 645 P2d at 325 (same); Vasquez $v$ State, 491 SW2d 173, 174-75 (Tex Crim App 1973) (same).

B These laws, for example, prohibit sexual intercourse (and most sexual contact) with prepubescent girls (usually age twelve and under); prohibit older, adult men from having sexual intercourse with younger adolescents (under fifteen, for example); and allow adolescent females the freedom to experiment sexually with their peers. For examples of these statutes, see notes 16-23 and accompanying text. For comprehensive, fifty-state surveys of age-of-consent statutes, see William N. Eskridge, Jr. and Nan D. Hunter, Sexuality, Gender and the Law 1021-22 (Foundation 1997); Charles A. Phipps, Children, Adults, Sex and the Criminal Law: In Search of Reason, 22 Seton Hall Legis J 1, $43-77$ (1997); Richard A. Posner and Katherine B. Silbaugh, A Guide to America's Sex Laws 44-64 (Chicago 1996).

6 See, for example, 21 Okla Stat Ann §§ 1111-12, 1114 (West 1983 \& Supp 1998); Ariz Rev Stat Ann § 13-1405 (West 1989) (setting age at eighteen); Idaho Code § 18-6101(a) (1997). 
specify aggravating factors-focusing exclusively on the male defendant's conduct - to increase the defendant's punishment beyond the presumptive minimum. Removing victim conduct from a court's decision to sentence the defendant will ensure that the expressive message the court sends through punishment both accords with the defendant's true culpability and does not inappropriately judge or devalue the victim.

Part I of this Comment provides an overview of modern statutory rape laws and describes how courts have considered victim conduct in statutory rape prosecutions. Part II outlines the policy goals underlying statutory rape laws. Part III analyzes how mitigation of punishment based on victim conduct hinders the realization of these policy goals. Finally, Part IV argues that mitigation based on victim conduct is a destructive strategy, recommends that courts not use victim conduct in making sentencing decisions, and proposes an alternative sentencing solution.

\section{AN OVERVIEW OF STATUTORY RAPE LAW}

\section{A. Developments in Statutory Rape Law}

The age of consent has historically served as a bright line rule classifying sex with young females as "statutory rape," a particular type of forbidden sexual conduct. As a bright line, strict liability rule, this classification aided courts in their administration of the law; rather than delve into the particularities of each situation, such as the defendant's mental state or the vulnerability of the victim, courts had only to determine the age of the female and whether the defendant engaged in sexual relations with her. ${ }^{7}$

This regime was workable when laws set the age of consent between ten and twelve years of age. ${ }^{8}$ Below these ages, sexual activity is generally conceded to be socially undesirable, in part because it is physically and emotionally dangerous for the young female involved. ${ }^{9}$ Therefore, with a low age of consent, society had little need to worry about the relative culpability of defendants' conduct.

' See Laurie L. Levenson, Good Faith Defenses: Reshaping Strict Liability Crimes, 78 Cornell L Rev 401, 402-06 (1993) (explaining the rationale behind criminal strict liability).

${ }^{8}$ See Mary E. Odem, Delinquent Daughters: Protecting and Policing Adolescent Female Sexuality in the United States, 1885-1920 14-15 (UNC 1995) (listing legal ages of consent in 1885 between seven and twelve).

- See Phipps, 22 Seton Hall Legis J at 33 (cited in note 5) ("The fundamental theme articulated throughout the years is the understanding that the wrongfulness of sexual conduct with young children is so obvious that courts and legislatures have little need to expand on the premise."). 
However, in the wake of the "social purity" movement ${ }^{10}$ at the beginning of the twentieth century, legislatures increased the age of consent, often to seventeen or eighteen years of age. ${ }^{11}$ This age increase introduced problems of relative culpability into the law of statutory rape, because-unlike the case of a sexual relationship with a girl below ten or twelve years old-it is not always clear whether sex with an adolescent female is dangerous or morally undesirable. ${ }^{12}$ For example, in the first half of this century, although sex with young girls was frowned upon, it was less morally reprehensible if the young female in question was already sexually active. Today, on the other hand, the ambiguity stems from society's permissive attitude toward teenage sexual experimentation. Both then and now (although for starkly different reasons), courts have used mitigation based on victim conduct to align the male defendant's punishment with his culpability according to community moral standards. Notwithstanding this ambiguity, and even after the sizable increase in the age of consent, states continue to mete out harsh punishments for statutory rape, including life imprisonment. ${ }^{13}$

Although some states continue to have bright line age-ofconsent statutes on the books, ${ }^{14}$ most states have recognized that such laws are ill-adapted to the contemporary complexity of sexual relationships. Moreover, given the considerable individual

${ }^{10}$ See Odem, Delinquent Daughters at 8-12 (cited in note 8 ) (describing the various groups fighting for higher age-of-consent laws).

"Id. Some states continue to set the age of consent as high as seventeen or eighteen. See, for example, Ariz Rev Stat Ann § 13-1405 (West 1989); Cal Penal Code § 261.5 (West 1998). In four states, the most serious penetration offense is set below age ten or eleven. Phipps, 22 Seton Hall Legis J at 58 table 1 (cited in note 5).

${ }^{12}$ See, for example, Roberto Suro, Town faults law, not boy in sex case, Wash Post AI (May 11, 1997) (describing community outrage over the prosecution and conviction of an eighteen year old man for having sex with his fifteen year old girlfriend; under the law, he faces up to forty years in prison and will have his name listed on a national directory of sex offenders). See also Patricia Edmonds, Teen pregnancy revives laws on statutory rape, USA Today 1A (Mar 28, 1996) (describing the influence of the sexual revolution and sexual mores on statutory rape reform in the 1960s and 1970s).

${ }^{13}$ See, for example, Smotherman $v$ Beto, 276 F Supp 579, 581 (N D Tex 1967) (sentence of ninety-nine years for statutory rape); Duckworth $v$ State, 833 SW2d 708, 709 (Tex App 1992) (sentence of forty-five years for aggravated sexual assault of a child); State $v$ Nice, 103 Idaho 89, 645 P2d 323, 323 (1982) (maximum possible sentence of life in prison). See also Phipps, 22 Seton Hall Legis $J$ at 72 \& $n 281$ (cited in note 5) (classifying as felonies those child sex offenses that "provide a penalty of death or more than one year in prison").

"See, for example, 11 Del Code Ann $\S \S 768,770$ (Michie 1987 \& Supp 1997) (setting age at sixteen); Kan Stat Ann § 21-3503 (1988) (barring indecent liberties with a child who is not married to defendant and who is under sixteen years of age); Mass Gen Laws ch $265, \S 23$ (Michie/Law Co-op 1980) (criminalizing "sexual intercourse or unnatural sexual intercourse" with a child under sixteen). 
variation in the rate of adolescent development, imposing a rigid age-based rule is problematic when one of the parties is an adolescent. ${ }^{15}$ Because girls are emotionally and physically prepared to assume responsibility for sex at different ages, a particularistic approach that considers their individual stage of development may better protect them while also respecting their autonomy. Consequently, many states now use graduated statutory schemes to define acceptable sexual behavior. ${ }^{16}$ These schemes attempt to protect young females from premature or coercive sexual relationships while acknowledging the realities of adolescent sexuality and experimentation. These graduated schemes have three main variations.

First, some states distinguish prohibited from permitted conduct based on the type of sexual act and the age of the minor. ${ }^{17}$ In Michigan, for example, sexual contact of any kind with a child below the age of thirteen is forbidden; between the ages of thirteen and fifteen, the child is presumed capable of consenting to sexual activities like petting, but is presumed incapable of consenting to intercourse; beginning at age sixteen, the child is deemed capable of consenting to sexual intercourse. ${ }^{18}$ Such graduated schemes may reflect the legislatures' conceptions of the relative harmfulness of different sexual activities at various ages.

Second, some states define defendants' culpability solely on the age of the victim. ${ }^{19}$ These states distinguish among cases by

${ }^{15}$ This is particularly true of bright line rules based on age, because age is often an unsatisfactory indicator of emotional, physical, and sexual maturity. See MPC § 213.1 at 327-29 (ALI 1980) (describing this line-drawing problem); James P. Semmens and F. Jane Semmens, Physiological Growth and Emotional Adjustment of Adolescent Girls, in James P. Semmens and Kermit E. Krantz, eds, The Adolescent Experience: A Counseling Guide to Social and Sexual Behavior 50-51 (MacMillan 1970) (describing the physical developments that occur during adolescence as a highly individual process, particularly in the United States with the mixing of races, ethnicities, and regional backgrounds). Moreover, adolescents exploit their "dual" status, claiming to be adults when they desire autonomy and "kids" when they want to avoid responsibility. See Sharon Thompson, Going All the Way: Teenage Girls' Tales of Sex, Romance, and Pregnancy 229-30 (Hill \& Wang 1995).

${ }^{16}$ For a description of such a graduated scheme, see People v Cash, 419 Mich 230, 351 NW2d 822, 826-28 (1984).

${ }^{17}$ See, for example, Ariz Rev Stat Ann $\$ \S 13-1404,13-1410$ (touching the "private parts" and sexual contact that "involves the female breast"); ILCS ch 720, $\S \S 5 / 12-12(\mathrm{e})$, 5/12-15 (Supp 1998) ("sexual conduct" such as touching the victim's "sexual organs, anus or breast”). See also Phipps, 22 Seton Hall Legis J at 46-47 \& nn 190-95 (cited in note 5) (describing "sexual contact" offenses and listing corresponding state statutes).

${ }^{18}$ Mich Comp Laws Ann § 750.520 (b)-(d) (West 1991).

19 Using age to enhance a sentence for a statutory rape conviction is not a new practice. In fact, it was "integral to the common law construction of statutory rape." Michelle Oberman, Turning Girls into Women: Re-Evaluating Modern Statutory Rape Law, $85 \mathrm{~J}$ Crim L \& Criminol 15, 25 (1984). 
categorizing the crime as a felony or misdemeanor based on the age of the victim. The majority of these states set the age of consent somewhere between thirteen and fifteen years of age. For example, in Maryland, where the age of consent is fifteen, intercourse with a girl of fourteen years or younger is a felony, while intercourse with a girl of fifteen is a misdemeanor (assuming that the male is more than four years older than the victim). ${ }^{20}$

Third, some states create narrow exceptions to the statutory rape laws by defining a range of age differences between defendants and victims inside of which sexual intercourse is permissible. For example, some states only prohibit sexual relations between adults (persons above the age of legal majority) and persons below the age of consent, thus permitting consensual sexual relations between minors. ${ }^{21}$ Other states prohibit sexual acts where the male defendant is a certain number of years or months older than the victim. ${ }^{22}$ For example, in Iowa, criminal penalties do not attach when both parties are at least fourteen and the older party is less than six years older than the younger party. ${ }^{23}$

\section{B. The Use of Victim Conduct}

Statutory rape laws express society's view that girls under a certain age are not capable of consent. By casting this view as an irrebuttable presumption, statutory rape laws allow prosecutors and judges to avoid probing the minds of young girls to determine their level of development and whether or not they were capable of giving informed consent to sexual relations. Therefore, evi-

${ }^{20}$ Md Ann Code art 27, $\S 463(a)(3), 464 C(a)(2)$ (Michie 1996). See also Ky Rev Stat Ann $\$ \S 510.040,510.050$ (Michie 1990) (defining first degree statutory rape as sexual intercourse with a victim who is younger than twelve years of age and second degree statutory rape as sexual intercourse with a victim between the ages of twelve and fourteen).

${ }^{21}$ See, for example, Neb Rev Stat $\S 28-319(1)(c)$ (1985) (prohibiting sexual contact between adults over nineteen and minors under sixteen); Nev Rev Stat §§ 200.364(3), 200.368 (1995) (criminalizing sexual contact between persons older than eighteen and younger than sixteen); Ky Rev Stat Ann $\$ 510.060$ (Michie 1990) (barring intercourse between twenty-one year old adults and persons under eighteen).

${ }^{2}$ See, for example, Md Ann Code art 27, $\$ 463,464 B$ (Michie 1996) (criminalizing sexual intercourse with persons under fourteen if the defendant is at least four years older than the victim and sexual intercourse with a fourteen or fifteen year old if the other person is at least twenty-one); La Rev Stat Ann §§ 14:80-81 (West 1986) (criminalizing "indecent behavior" between persons over seventeen and victims two years younger); Minn Stat Ann $\S \S 609.342,609.344$ (West 1987) (varying sentences depending on the age of the victim and the defendant).

${ }^{23}$ Iowa Code Ann $\S \S 702.17,709.1,709.3,709.4$ (West 1998). The age band can either be fairly broad, as in this example, or fairly narrow. For an example of a narrow band, see Minn Stat $\$ \S 609.342-345$ (Supp 1997) (defining band as low as twenty-four months); Tex Penal Code $\$$ 21.11(b)(1), 22.011(e) (West 1994 \& Supp 1997) (defining band as three year age difference where the victim is under seventeen). 
dence indicating a girl's actual consent is irrelevant. ${ }^{24} \mathrm{~A}$ statutory rape victim's conduct is not a defense to the crime, and evidence of victim conduct may not be presented at trial..$^{25}$ Nonetheless, there are a number of ways that defendants can circumvent the exclusion of evidence about the victim's prior sexual experience, reputation, consent to the sex act, or initiation of the sexual contact. $^{26}$

\section{Challenging the victim's credibility.}

The defendant may introduce evidence of the victim's sexual history to challenge the victim's testimonial credibility. For example, if the victim claims she was a virgin before the defendant had intercourse with her, evidence that she had previously engaged in sexual acts may be used to impeach her testimony. ${ }^{27}$ In

${ }^{24}$ See Donald E.J. MacNamara and Edward Sagarin, Sex, Crime, and the Law 67 (Free Press 1977) (''Statutory rape' usually refers to ... a consensual act in that both parties agreed but one legally regarded as a form of rape because the age and presumed immaturity of the female did not give her the legal right to offer consent."). See also People $v$ Roach, 129 Cal 33, 61 P 574, 574 (1900) ("[N]either the element of force, nor the question of consent has any application. The prosecutrix could not consent, and the law resists for her."); Cash, 351 NW2d at 829 (holding that the "victim below the age of consent is . . . legally incapable of giving his or her consent to sexual intercourse").

${ }^{2}$ See Vasquez $v$ State, 491 SW2d 173, 174-75 (Tex Crim App 1973) (holding evidence of chastity to be inadmissible for conviction but admissible for sentencing); Keith $v$ State, 121 Tex Crim 508, 51 SW2d 603, 604 (1931) (holding that previous unchastity is no defense where the girl is under fifteen years of age); Barton v Bee Line, 265 NYS 284, 285 (App Div 1933) (noting that consent is no defense to criminal charges for statutory rape); Lusty $v$ State, 97 Tex Crim 167, 261 SW 775, 776 (1924) (holding that, in general, the victim's sexual contacts are not material).

${ }^{26}$ For exceptions to the federal rape shield law, see FRE 412(b), which excepts evidence to show: (1) a person other than the accused was the source of physical evidence, and (2) other sexual acts with defendant. Because relatively few cases specifically address the situation of an underage girl initiating sexual contact, this Part also discusses the victim's previous sexual history and consent to the sex act. Doing so does not muddy the analysis, however, because courts have treated these types of victim conduct interchangeably.

${ }^{27}$ Similarly, where an underage victim alleges that she was forcibly raped, courts have allowed evidence of her prior sexual relationships in order to impeach her testimony. See Lusty, 261 SW at 777; Duty $v$ Texas, 114 Tex Crim 420, 25 SW2d 834, 835 (1930). The rationale behind introducing sexual history evidence in this context is based on the discredited notion that if a female has consented to sex once, her consent to later sexual activity can be inferred. See Odem, Delinquent Daughters at 70 (cited in note 8). Despite the enactment of rape shield laws to protect rape victims during trial, it is not clear how rape shield laws should be applied to children and adolescents who were victims of child sexual abuse. See, for example, New Jersey v Budis, 125 NJ 519, 593 A2d 784, 788-89 (1991) (allowing evidence of the nine year old victim's history of sexual abuse only to show a potential source for the infant's sexual knowledge). The result in this case prompted the dissent to point out the "cruelest paradox": "because of an assumption that children are naive and innocent, the majority believes we must counteract that assumption by permitting the very indignities to be inflicted on this child victim that we would not inflict on an adult victim." 593 A2d at 797 (O'Hern dissenting). 
addition, where the defendant denies that the sexual encounter occurred, evidence of the victim's prior sexual relationships may be introduced to rebut the inference-based on the victim's physical condition or knowledge of sexual practices-that the defendant is guilty. For example, where the victim is pregnant, has a venereal disease or a damaged hymen, or exhibits unusual knowledge about sexuality for someone her age, the defendant may introduce evidence of the victim's sexual history in order to demonstrate that her condition could be the result of sexual relationships with someone else. ${ }^{28}$

\section{Nullifying the age of consent.}

Where the defendant admits the sexual encounter, some courts have allowed evidence of the victim's sexual experience and sophistication to override or nullify the statutorily defined age of consent. In effect, previous sexual experience renders the victim capable of consenting in fact. The rationale underlying these decisions is that sexually experienced girls understand the benefits and risks associated with sexual activity and can make rational, informed decisions. ${ }^{29}$ Furthermore, courts explain that the state's goal is to protect the innocent and the naive, because they are the victims least likely to recognize the consequences of premature sexual activity. ${ }^{30}$ Accordingly, the courts reason that the legislature did not intend to protect sexually experienced adolescents. ${ }^{31}$ These courts engage in the questionable practice of turning an irrebuttable presumption into one that can be rebutted.

\section{Mitigating the defendant's punishment.}

The third exception allows the defendant to introduce evidence of the victim's sexual history, consent to the sex act, or in-

${ }^{23}$ See Lusty, $261 \mathrm{SW}$ at 776; New Hampshire v Cressey, $137 \mathrm{NH}$ 402, 628 A2d 696, 703 (1993) (remanding an aggravated sexual assault case to examine defendant's evidence regarding child's prior consensual sexual conduct); State $v$ Kraus, 175 Minn 174, $220 \mathrm{NW}$ 547,549 (1928) (rejecting defendant's evidence regarding child's other illicit relations while noting that such evidence may be relevant if the child is pregnant); Budis, 593 A2d at 788, 791-92.

${ }^{2}$ See discussion of this rationale in Alston $v$ Texas, 1991 Tex App LEXIS 2366, *4-8 (unpublished opinion), and B.B. v State, $659 \mathrm{~S} 2 \mathrm{~d}$ 256, 259 (Fla 1995).

${ }_{30}$ See Cash, 351 NW2d at 826-27; People v Hernandez, 61 Cal 2d 529, 393 P2d 673, 674 (1964).

${ }^{31}$ See Idaho $v$ Stiffler, 114 Idaho 935, 763 P2d 308, 311 (1988); B.B., 659 S2d at 260-61 (Kogan dissenting). See also Gerhard O.W. Mueller, Sexual Conduct and the Law 54 (Oceana 2d ed 1980) (" $[T]$ he criminality of statutory rape seeks to protect the purity of young girls."). 
stigation of the sexual activity in order to mitigate his punishment. ${ }^{32}$ Courts mitigating punishment based on the victim's conduct seldom explain how mitigation furthers the specific goals of statutory rape laws or the goals of criminal law more generally. Furthermore, these courts do not explain why the victim's past sexual behavior is a valid reason for adjusting the penalty even though it is not a defense to the crime itself.

\section{THE POLICY GOALS UNDERLYING STATUTORY RAPE LAWS}

Legislatures designed early statutory rape laws to protect young females' virginity ${ }^{34}$ in order to ensure their eligibility for marriage..$^{35}$ At the turn of the century, reformers and families used statutory rape laws both to protect and to control the sexuality of working class girls laboring in the new urban centers. ${ }^{36}$ Today, two interrelated policy goals continue to motivate legislators to retain a statutory age of consent: (1) to prevent teenage girls from consenting to sex in an uninformed manner, thereby exposing themselves to physical and emotional harm; and (2) to

${ }^{32}$ See, for example, Fry $v$ Virginia, 163 Va 1085, 177 SE 860, 862 (1935) (moral character); Lusty, $261 \mathrm{SW}$ at 777 (previous sexual contacts); State $v$ Thompson, $289 \mathrm{SW} 788$, 789 (Mo 1926) (lack of chastity); King $v$ State, 106 Ark 160, 152 SW 990, 991 (1913) (prior sexual contacts); Nice, 645 P2d at 325 (female's provocative behavior); State $v$ Rush, 24 Kan App 2d 113, 942 P2d 55, 57 (1997) (victim sexual aggression); Arizona v Bartlett, 171 Ariz 302, 830 P2d 823, 828 (1992) (willing consent). See also Odem, Delinquent Daughters at 78-79 (cited in note 8) (describing pattern of lenient sentencing in cases involving females of "dubious character"). But see Heath $v$ Indiana, 173 Ind 296, 90 NE 310, 314 (1909) (finding victim's chastity irrelevant); West $v$ State, 141 Tex Crim 233, 147 SW2d 791, 793 (1941) (rejecting evidence that child played with "negro boys").

${ }^{3}$ One exception to courts' silence regarding the relevance of victim sexual history is the use of force. Juries are likely to exact a higher penalty where force was used. Therefore, if the victim's conduct indicates that force was not used, courts have allowed that evidence to prevent the jury from assuming the defendant used force and imposing a higher penalty based on this assumption. For an explanation of this rationale, see Vasquez, 491 SW2d at 174-75 (tracing several cases where the judge allowed evidence of victim conduct to counteract the jury's tendency to impose a higher penalty in cases where force was alleged).

${ }^{34}$ See Oberman, $85 \mathrm{~J}$ Crim L \& Criminol at 27-28 (cited in note 19); Odem, Delinquent Daughters at 71 (cited in note 8).

${ }^{35}$ See Maryanne Lyons, Comment, Adolescents in Jeopardy: An Analysis of Texas' Promiscuity Defense for Sexual Assault, 29 Houston L Rev 583, 586-87 (1992); Oberman, $85 \mathrm{~J}$ Crim L \& Criminol at 25-26 (cited in note 19) (explaining that women's status as "special property" was deserving of protection only in its pure, unblemished form).

${ }^{36}$ See Odem, Delinquent Daughters at $20-25$ (cited in note 8 ). This is one example of how statutory rape laws have enforced norms of sexual behavior. For example, during the Industrial Revolution, many young people-particularly working class young womengathered in cities, working away from the home and beyond their parents' control. Statutory rape laws helped working class families control free-spirited daughters and their sexual partners by holding working class girls to "a code of sexual morality based on middle-class values of female sexual restraint." Jane E. Larson, "Even a Worm Will Turn at Last": Rape Reform in Late Nineteenth Century America, 9 Yale J L \& Human 1, 65 1997). 
deter men from preying on young females and coercing them into sexual relationships. ${ }^{37}$ These two problems are not completely distinct; however, one should consider them separately, as the first goal focuses primarily on the female and the second primarily on the male. Nevertheless, in both cases, the harm resulting from the adult-teenage sexual relationship is the same: the risk of physical (pregnancy, sexually transmitted disease) and emotional (dysfunction) harm. ${ }^{38}$

\section{A. Protecting Girls From Themselves: Ensuring Informed Consent}

Age-of-consent statutes protect young females by legally nullifying their ability to consent to sexual intercourse ${ }^{39}$ Young girls, it is argued, lack the maturity, experience, or worldliness to understand the risks and dangers associated with sexual intercourse. ${ }^{40}$ They are therefore presumed by law to be unable to consent to sexual relations in a meaningful and informed manner. ${ }^{41}$

${ }^{37}$ These two rationales are intertwined, as demonstrated most clearly in the recent movement to tighten up statutory rape laws in response to studies indicating that often adult men father children born to teenage mothers. See Edmonds, Teen pregnancy, USA Today at 1A (cited in note 12) (describing concern over adult "predators" who seek out sexual relations with young females who are not yet prepared to make informed decisions about sex); Frank Reeves, Father figures, Pittsburgh Post-Gazette A1 (Sept 10, 1995) (describing the problems of coercion in adult-teenage sexual relations and young females' problems understanding the risks associated with sex). Progressive reformers expressed similar concerns at the close of the nineteenth century when they pressed for increases in the statutory age of consent. See Odem, Delinquent Daughters at 16-18 (cited in note 8) (describing the social purity movement's conception of male predation); Larson, 9 Yale J L \& Human at 8-10 (cited in note 36) (recounting reformers' concern that the low age of consent did not adequately protect young females from sexual misjudgment, particularly as compared with the high age of consent required for contractual relations).

${ }^{38}$ For a description of the harms that may arise from adult-adolescent sexual relations, see Phipps, 22 Seton Hall Legis $J$ at 124-27 (cited in note 5).

${ }^{30}$ See People $v$ Cash, 419 Mich 320, 351 NW2d 822, 829 (1984) (" $[$ T'] here is no issue of consent in a statutory rape charge because a victim below the age of consent is conclusively presumed to be legally incapable of giving his or her consent to sexual intercourse."). See also Parsons $v$ Parker, $160 \mathrm{Va} \mathrm{810,170} \mathrm{SE} \mathrm{1,} 2$ (1933) ("The effect of the statute is to render her in law incapable of giving her consent to the sexual act ....").

${ }^{40}$ See Judith Ennew, The Sexual Exploitation of Children 62 (St Martin's 1986) (describing the inability of children to consent in an informed manner to sexual activity); Seymour L. Halleck, Emotional Effects of Victimization, in Ralph Slovenko, ed, Sexual Behavior and the Law 673, 677 (Charles C. Thomas 1965) (stating that fourteen year olds are emotionally immature and incapable of making reasonable judgments about sexual behavior); Semmens and Semmens, Physiological Growth at 57 (cited in note 15) (stating that females' emotional development lags several years behind their physical development).

${ }^{41}$ Age-of-consent statutes use age as a proxy to determine when a teenage girl is capable of informed consent. Because age is an imperfect proxy, however, the statutes are both over- and underinclusive. As a result, even those teenage girls who are in fact sufficiently emotionally mature to appreciate their decision are deemed legally incapable of consent. 
Young adolescents who engage in sexual activity with adults may experience long-term emotional scars that impair their sexual and romantic relationships as adults. ${ }^{42}$ Prepubescent sexual activity-particularly intercourse-can also cause physical damage to sexual organs that are not fully developed. In addition, young females making uninformed decisions to engage in sex need to be protected from the significant risks of pregnancy and sexually transmitted diseases. ${ }^{43}$

Paternalism motivates this understanding of statutory rape: adolescent females must be protected from themselves. Paternalistic protection denies teenage girls the opportunity to behave autonomously. ${ }^{44}$ However, it may be appropriate here because adolescent girls, after all, are not adults. They generally do not have adult responsibilities and are not allowed to make adult decisions in many other areas of their lives. For example, girls and boys under sixteen generally may not drink alcohol, buy tobacco

At one time, this rationale was used to protect girls from improperly disposing of their sexual "treasure." James A. Durham, Forcible and Statutory Rape: An Exploration of the Operation and Objectives of the Consent Standard, 62 Yale L J 55, 76 (1952).

${ }^{42}$ See Heidi Kitrosser, Meaningful Consent: Toward a New Generation of Statutory Rape Laws, 4 Va J Soc Pol \& L 287, 323-26 (1997) (describing problems of self-esteem and identity formation that may develop in unhealthy sexual relationships during adolescence); Phipps, 22 Seton Hall Legis J at 90-95, 97-98, 125 (cited in note 5) (describing emotional effects of sexual abuse and stating that the effects of sexual abuse are not strictly related to the age of the victim and even older children and adolescents may experience emotional harm). But see Eskridge and Hunter, Sexuality, Gender and the Law at 1033-34 (cited in note 5) (reviewing research showing that even eroticized relations between two young adolescents may not result in social and emotional pathology).

${ }^{43}$ See MacNamara and Sagarin, Sex, Crime, and the Law at 21 (cited in note 24) ("The major criminal source of unwanted pregnancy and illegitimacy is probably statutory rape ...."); Guttmacher Institute, Sex and America's Teenagers 53 (Guttmacher 1994) ("For a sizable minority of young women [ 30 percent of fifteen year olds] becoming mothers, the father of the baby is considerably older-by six years or more."). This logic was affirmed by the Supreme Court in Michael M. v Superior Court, 450 US 464, 470-73 (1981) (describing teenage pregnancy as a valid reason for California's gender-specific age of consent statute). In addition, three million adolescents become infected with a sexually transmitted disease ("STD") every year; STDs often affect females disproportionately, because they are more difficult to detect in females, making complications from undiagnosed conditions more likely. See Guttmacher Institute, Sex and America's Teenagers at 38-39. But see Thompson, Going All the Way at 238 (cited in note 15) (finding that teenage girls were more, not less, likely to take precautions against pregnancy when they were involved with adult men as opposed to teenage boys).

"See Kitrosser, $4 \mathrm{Va} J \mathrm{~J}$ So Pol \& L at 288 (cited in note 42) (noting that some feminists believe that "[s]tatutory rape laws violate female autonomy and thus deny young women the right to choose when and with whom they will engage in sexual activity") (citations omitted); Larson, 9 Yale J L \& Human at 66-67 (cited in note 36) ("[S]ome modern feminists have opposed strong statutory rape laws on the ground that such laws restrain the sexual freedom of girls, and thus represent a repressive and puritanical control of female sexuality."); Odem, Delinquent Daughters at 25 (cited in note 8) ("The moral protection offered by middle-class reformers, then, came at a high price. It demanded adherence to a rigid code of morality that denied women sexual desire and agency."). 
products, marry, drive, or vote. ${ }^{45}$ Because the risks associated with sex are so great, society's paternalistic treatment of girls in this context may be justified.

Like the common law practice of allowing minors to void their contracts, ${ }^{46}$ age-of-consent statutes seek to discourage adults from taking advantage of minors' vulnerability and to protect minors from their own folly and immaturity. ${ }^{47}$ In the contract context, adults are deterred from exploiting minors because they risk losing the benefits of the contract. ${ }^{48}$ In sexual relations, however, the benefits of the sex act cannot be denied once the act has taken place. ${ }^{49}$ Therefore, deterrence is achieved through criminal prosecution. ${ }^{50}$

\section{B. Combating Male Predation: Protecting Teenage Girls From Coercive Sexual Relations}

Because of their youth, gender, and emotional immaturity, young females may not only be unable to make informed decisions, but they may also be vulnerable to coercion. Adults and adolescents do not have equal bargaining power: young adolescents (especially females) are generally physically smaller and weaker than adults; adolescents lack the experience and worldliness that adults have; and adolescents rely on adults for food, shelter, and economic support. ${ }^{51}$ Moreover, adolescents are infe-

${ }^{45}$ See Lyons, Comment, 29 Houston L Rev at 619-20 (cited in note 35); Robyn-Marie Lyon, Speaking for a Child: The Role of Independent Counsel for Minors, 75 Cal L Rev 681, 682-83, 696 (1987).

${ }^{45}$ See E. Allan Farnsworth, 1 Contracts $\$ 4.4$ at 379-80 (Little, Brown $2 d$ ed 1990) (noting that at common law, minors could unilaterally void their contracts).

${ }^{47}$ See id $\& 4.3$ at 377-79. See also Oberman, $85 \mathrm{~J}$ Crim L \& Criminol at $43-46$ (cited in note 19) (discussing how the common law of contracts protects minors from commercial folly; because they may void contracts, "[m]inors are legally unavailable for commercial exploitation").

${ }^{4}$ See Farnsworth, 1 Contracts $\$ 4.5$ at $383-90$ (cited in note 46), citing Sternlieb $v$ Normandie National Sec Corp, 263 NY 245, 188 NE 726, 728 (1934) (stating that, in most jurisdictions, adults contract with minors "at their peril").

${ }^{19}$ Deterrence may also be achieved through civil damages suits. See, for example, Barton $v$ Bee Line, 265 NYS 284, 285 (NY App Div 1933) (allowing civil damage suits); Parsons, $170 \mathrm{SE}$ at 3 (same).

${ }^{50}$ The slang term "jailbait" for adolescent females is evidence of this strategy's effectiveness in, if nothing else, making men aware of the consequences of having sexual relations with girls.

${ }^{61}$ See Ennew, Sexual Exploitation of Children at 62 (cited in note 40) (describing the power differentials between adults and children); Odem, Delinquent Daughters at 56-57 (cited in note 8) (describing the power differentials between young females and older males at the turn of the century); Phipps, 22 Seton Hall Legis J at 120 (cited in note 5) (describing adult control over children and adolescents). 
rior to adults in social hierarchies; this may be especially true for young females growing up in our patriarchal society. ${ }^{52}$

For these reasons, society presumes that sexual relations between children and adults involve some level of coercion against which the law must protect adolescent females. ${ }^{53}$ Even in the absence of physical force or violence, an adult man can coerce or manipulate a young female into sexual relations. Like Humbert, he can bribe his Lolita with gifts of clothing and candy; he can take her to unfamiliar places; and he can make her feel dependent on him (for love, for money, for attention). ${ }^{54}$ Unlike adult women, girls are relatively ill-prepared to extricate themselves from uncomfortable situations, to tell a man to stop, and to distinguish true declarations of feeling from manipulative flattery. ${ }^{55}$

Again, an analogy to the law of contracts is useful. Contracts are premised upon a bargain struck between two parties: each party decides that it is in her own best interest to make the contract. The common law, however, does not enforce contracts made under undue influence-where one party coerces or manipulates the other-because in these circumstances the contract does not reflect the free will of both parties. ${ }^{56}$ This doctrine may also in-

${ }^{82}$ See Oberman, $85 \mathrm{~J}$ Crim L \& Criminol at 35-36 (cited in note 19) (describing the work of feminists who focus on power differentials and believe teenage girls need protection from coercion, pressure, and the consequences of sex); id at 57 (surveying psychological literature of girls' adolescence as a time when girls confront a "patriarchal culture"); Francis Olsen, Statutory Rape: A Feminist Critique of Rights Analysis, 63 Tex L Rev 387, 397-98 (1984) (discussing the work of Nadine Taub and Catherine MacKinnon). But see Thompson, Going All the Way at 229-31 (cited in note 15) (finding that young adolescents involved with older men "did not share the adult belief that age differences imply inequality").

33 See Oberman, $85 \mathrm{~J}$ Crim L \& Criminol at $32 \mathrm{n} 87$ (cited in note 19) (describing the drafting of the Illinois age-of-consent statute and the drafters' decision to isolate and criminalize sexual conduct that they felt raised a presumption of coercion, primarily because of the age difference between the defendant and the victim); Guttmacher Institute, Sex and America's Teenagers at 28 (cited in note 43) (claiming the likelihood of coercive or involuntary sexual intercourse is inversely related to the age of the girl), citing K.A. Moore, C.W. Nord, and J.L. Peterson, Nonvoluntary Sexual Activity Among Adolescents, 21 Fam Plan Persp 110 (1989).

* See Reeves, Father figures, Pittsburgh Post-Gazette at A1 (cited in note 37) ("Many younger girls are ... drawn in by the prospects of lavish gifts or the prestige of knowing a young man who has a car.").

ss See Semmens and Semmens, Physiological Growth at 58 (cited in note 15) (stating that young females are emotionally immature despite their physical development and that they are unprepared to deal with the advances and interest that their appearance provokes); Olsen, 63 Tex L Rev at 424 (cited in note 52) (“'T] he primary justification for statutory rape laws is that women in our society do not have enough power to resist coercive male initiative in sex.").

${ }^{56}$ See Farnsworth, 1 Contracts $\S 4.20$ at 447 (cited in note 46 ) ("[T] tion is whether the result was produced by means that seriously impaired the free and competent exercise of judgment."). 
clude the situation where the "weaker party is for some reason under the domination of the stronger. 957

Similarly, by codifying the presumption of some sort of undue influence or coercion in adult-adolescent sexual relations, statutory rape laws invalidate a young female's consent to sexual intercourse. This presumption protects young females by removing the heavy burden on the state and the victim to prove that coercion or force was actually used (avoiding the many problems associated with convicting a defendant of forcible rape). Furthermore, by labeling sexual intercourse between men and adolescent girls "statutory rape," the criminal law conceptually compares forcible rape to adult sex with young females ${ }^{58}$ and grafts the associations and social meaning of forcible rape onto sex with underage females. ${ }^{59}$ Under this conception, a man uses constructive force (thereby committing rape) when he has sex with a teenage girl who is presumptively ill-equipped to withstand the dynamics of the situation and who therefore cannot freely consent to sex. ${ }^{60}$ Therefore, defendants of varying degrees of culpability are treated the same by the law. This situation creates community pressure on courts to distinguish among defendants based on whether they used force or not. One means of doing so has been for courts to focus on the victim's behavior, as a backdoor means of reinserting consent into statutory rape.

\section{The EfFects of Mitigation ON POLICY GoAls}

This Part analyzes how mitigating the man's punishment when the victim initiated the sexual contact undermines the policy goals behind statutory rape laws. To undertake this analysis, this Part examines the interactions between four hypothetical ac-

${ }^{57}$ Id $\S 4.20$ at 446 . One can draw a similar analogy to the contract doctrine of unconscionability. See id $\$ 4.28$ at $495-517$.

s See MacNamara and Sagarin, Sex, Crime, and the Law at 80 (cited in note 24) ("The term 'statutory rape' . . . is not without its rationale. Rape itself is nonconsensual sexual behavior; a minor ... no matter how willing or eager, has not given consent because she is below the age at which she has the legal right or the social maturity to offer it.").

${ }^{89}$ See Lawrence Lessig, The Regulation of Social Meaning, 62 U Chi L Rev 943, 100912 (1995) (describing the semiotic technique of "tying," by which the social meaning of one act is transformed by associating it with the social meaning of another act). One problem with this construction, however, is that it fails to distinguish between forcible and consensual sexual intercourse with females below the age of consent. See Ralph Slovenko, $A$ Panoramic View: Sexual Behavior and the Law, in Slovenko, ed, Sexual Behavior and the Law 5, 58 (cited in note 40) (criticizing the appellation "statutory rape" because it does not reflect the abhorrence of the crime of rape).

${ }^{60}$ See MacNamara and Sagarin, Sex, Crime, and the Law at 27 (cited in note 24) ("When one party is a child, the law finds force implicit in the age differential."). 
tors: an immature young female, a mature young female, a coercive adult male, and a noncoercive adult male.

For this discussion, a mature young female will be defined as a girl whose decision to enter into a sexual relationship reflects "maturity of judgment." A young female with maturity of judgment is responsible and temperate. Her decision reflects a sense of context and perspective..$^{62}$ An immature female, on the other hand, is prone to be influenced by others, to act impulsively, and not to place her decision in its broader context. ${ }^{63}$

A coercive male will be defined as a man who uses his position, age, influence, or money to pressure his female partner into engaging in sexual intercourse. He may also seek to take advantage of a compromising situation or pressure her to engage in activities beyond those to which she initially consented. A noncoercive male, on the other hand, ensures that his female partner desires and freely consents to all sexual activity.

Obviously, people in real life do not fit into neat, discrete categories of "mature," "immature," "coercive," and "noncoercive. ${ }^{.64}$ Rather, people fit somewhere along a continuum; their behavior may change or vary according to the situation in which they find themselves. ${ }^{65}$ Nevertheless, these general categories can be useful in analyzing the dynamics that occur when adult men and young females engage in sexual relations.

The following table identifies the possible combinations between these four actors. As the remainder of this Part describes in more detail, in three of the four cases, mitigating the male defendant's punishment based on the female's provocative conduct has perverse effects. For this reason, courts should refuse to use victim conduct as a reason to mitigate a male defendant's punishment.

${ }^{61}$ Elizabeth Cauffman and Laurence Steinberg, The Cognitive and Affective Influences on Adolescent Decision-Making, 68 Temple L Rev 1763, 1764-65 (1995) (describing their model of "maturity of judgment").

"See id (describing the "core components" of maturity of judgment).

"For a discussion of adolescent decisionmaking that contrasts the "judgment" model with the "informed consent" (rational) model, see id at 1763-87; Elizabeth S. Scott, N. Dickon Reppucci, and Jennifer L. Woolard, Evaluating Adolescent Decision Making in Legal Context, 19 L \& Human Beh 221 (1995) (critiquing the informed consent model as applied to adolescents and recommending a judgment model).

" See Olsen, 63 Tex L Rev at 427-28 (cited in note 52) (describing the problem of placing sexual relations in sharply distinct categories).

es This is particularly true for adolescents. See Semmens and Semmens, Physiological Growth at 48 (cited in note 15) ("Adolescents normally vacillate from one sphere to the other [childhood to adulthood] in action, decision, and appearance."). Nonetheless, these categories help to analyze the issues raised by mitigating punishment in statutory rape by isolating the problems associated with different personal characteristics that the law aims to correct. 


\begin{tabular}{|l|l|l|}
\hline & \multicolumn{1}{|c|}{ Mature Young Female } & \multicolumn{1}{c|}{ Immature Young Female } \\
\hline $\begin{array}{l}\text { Non- } \\
\text { coercive }\end{array}$ & $\begin{array}{l}\text { CASE 1: Mitigation may be a good } \\
\text { policy choice, because the adoles- } \\
\text { cent girl is capable of informed } \\
\text { consent and the man did not co- } \\
\text { erce her. }\end{array}$ & $\begin{array}{l}\text { CASE 2: Mitigation is problem- } \\
\text { atic; even though the man did not } \\
\text { coerce the adolescent girl, she is } \\
\text { incapable of understanding her } \\
\text { actions and therefore needs the } \\
\text { law's protection. }\end{array}$ \\
\hline $\begin{array}{l}\text { Coercive } \\
\text { Adult Male }\end{array}$ & $\begin{array}{l}\text { CASE 3: Mitigation is problem- } \\
\text { atic; although the adolescent girl } \\
\text { is capable of informed consent, it } \\
\text { is likely that the man coerced her } \\
\text { by taking advantage of the power } \\
\text { differentials between them. }\end{array}$ & $\begin{array}{l}\text { CASE 4: Mitigation is highly } \\
\text { problematic; not only is the ado- } \\
\text { lescent girl incapable of informed } \\
\text { consent, but it is likely that the } \\
\text { man coerced her by taking advan- } \\
\text { tage of the power differentials be- } \\
\text { tween them. }\end{array}$ \\
\hline
\end{tabular}

\section{A. Using Sexually Provocative Behavior as a Proxy for Maturity}

Courts have often used a young female's sexually assertive behavior as a proxy for her emotional maturity and thus her ability to consent. That is, courts have assumed that if a young female behaves provocatively and seeks out an older male partner, she must understand what she is doing.

This argument is not without merit. ${ }^{66}$ For example, in Going All the Way, Sharon Thompson recounts the rational decisions of some adolescent females to initiate sexual relations with older men. ${ }^{67}$ The teenagers explain that they sought out older men for their first sexual experiences because they wanted to learn about sex from a knowledgeable partner and they believed sex with an older, experienced lover would be more pleasurable than intercourse with one of their inexperienced teenage peers. ${ }^{68}$

${ }^{68}$ Similar arguments have been made for using sexual history as a proxy for ability to consent. See, for example, Alston $v$ Texas, 1991 Tex App LEXIS 2366, *4-5 (1991) (unpublished opinion); Idaho $v$ Stiffler, 114 Idaho 935, 763 P2d 308, 311 (1988); MPC § 213.6(3) at 419-20. See also Lyons, Comment, 29 Houston L Rev at 596-600 (cited in note 35) (discussing the use of the promiscuity defense); Oberman, $85 \mathrm{~J} \mathrm{Crim} \mathrm{L} \mathrm{\&} \mathrm{Criminol} \mathrm{at} 21$ (cited in note 19) (considering whether individual characteristics should be taken into account in determining a young female's ability to consent and recognizing that "as a practical matter, those who are not legally competent often are sexually active").

"7 Thompson, Going All the Way at 217 (cited in note 15) (reporting that 10 percent of girls interviewed talked of actively choosing women or men five or more years older than themselves as sexual partners). Many of these girls described themselves as "hunters and seducers" of reluctant older men. Id at 231.

${ }^{68}$ Most adolescent girls do not describe their sexual experiences with peers as pleasurable. See Oberman, $85 \mathrm{~J}$ Crim L \& Criminol at 19 n 21, $64 \mathrm{nn}$ 291-93 (cited in note 19). 
In Case 1, where the man is not coercive, perhaps courts should mitigate the male defendant's punishment. Severely punishing adult men who were pursued by mature teenage girls will deter men from engaging in these relationships and deny these girls sexual opportunities, compromising their sexual freedom and autonomy. ${ }^{69}$ Mitigation restores this autonomy by reducing the deterrent effect of statutory rape laws. ${ }^{70}$ Moreover, reducing the man's punishment in this context recognizes and affirms the girl's decision. By acknowledging her active, conscious involvement in the sexual encounter (rather than treating her as a legal nonentity), courts can, through mitigation, reinforce the adolescent's worth and maturity by communicating that the law and society sufficiently respect her ability to decide when to engage in sexual relations.

Unfortunately, however, it may be impossible for courts (and men) to determine when, in fact, a young female is mature. A girl's sexually provocative conduct is often not a valid proxy for maturity; a girl may behave provocatively and still be unable to make informed decisions about sex. Thus, it is not easy to distinguish between Case 1 and Case 2. If in fact a sexual encounter fits within Case 2, where the female is immature and the man is not coercive, mitigating the man's punishment leads to perverse effects. It abandons and leaves unprotected those girls who are least able to make informed decisions regarding sexual conduct and who are, ironically, those most likely to make sexual advances.

Several points illustrate this problem. First, there is no reason to believe that simply because an adolescent girl behaves in a sexually provocative manner, she has a greater understanding of the risks and benefits of sex than her more demure friends. In

Girls involved in sexual relationships with adults, on the other hand, are more likely to report sexual pleasure. See Thompson, Going All the Way at 220-21, 233-34 (cited in note 15). In addition, young females may see older men as more desirable partners because they have a higher immediate earning potential than teenage boys. It should be noted, however, that this earning disparity dissipates over time. See Laura Duberstein Lindber, et al, Age Differences Between Minors Who Give Birth and Their Adult Partners, 29 Fam Plan Persp 61-66 (1997), available online at <http://206.215.210.5/pubs/journals/2906197. htmb (visited May 9, 1998).

A A similar argument can be made in the contractual sphere. See Farnsworth, 1 Contracts $\S 4.3$ at 378 (cited in note 46 ) (observing that rules allowing minors to void their contracts "may disadvantage minors by discouraging others from contracting with them").

${ }^{70}$ See Ennew, Sexual Exploitation of Children at 46-48 (cited in note 40) (discussing the work of a psychologist who suggests that nonabusive adult-child sex should be regarded as possible and arguing that "a rational legal framework would recognize that a child has a right to make a free choice of sexual partner, provided that the relationship excludes the use of force and is made with the child's informed consent"). 
fact, the opposite conclusion is equally plausible. For example, if a teenager really understands the negative consequences of having sex, she is likely to choose less risky alternatives to satisfy her need for affection, love, and attention. ${ }^{71}$ She therefore will not solicit sex by behaving in a sexually provocative manner. Furthermore, teenage girls may be unaware that men perceive their actions and appearance as invitations to a sexual encounter. ${ }^{72}$ For example, an older man may interpret the actions of a girl who is playful or who seeks some physical closeness (such as sitting on his lap) to have sexual connotations that the girl did not intend to communicate. ${ }^{73}$ In addition, girls may behave and dress in a sexy manner, mimicking women and girls on television and in magazines, without fully appreciating how men interpret this behavior. $^{74}$

Second, teenage girls who are sexually assertive may be more vulnerable and less capable of making rational decisions about sexual contact than their demure peers. Often, extremely vulnerable young females are the most promiscuous, using sex to get attention (that is, they "act out" sexually). For example, victims of childhood sexual abuse and girls with eating disorders are both prone to sexually aggressive behavior. ${ }^{75}$ In addition, many adolescent girls have low self-esteem ${ }^{76}$ and may use their sexuality in

${ }^{31}$ See Thompson, Going All the Way at 58-66, 76-78 (cited in note 15) (describing "popular" girls' ability to manage and cope with sexual pressure).

${ }^{72}$ See Semmens and Semmens, Physiological Growth at 57-58 (cited in note 15) (discussing the disconnect between the physical and emotional development of young girls and stating that females' emotions are several years behind their physical transformation into women); Slovenko, A Panoramic View at 57 (cited in note 59) ("Although the female is unconsciously the seducer, the responsibility is on the adult to restrain himself.").

${ }^{73}$ See, for example, Hosea $v$ Texas, 163 Tex Crim 335, 290 SW2d 907, 908 (1956) ("[T]he twelve year old girl had shown an interest in [the defendant], had sat on [the defendant's] lap and otherwise invited his attention, and enticed and encouraged his advances .... . [S]

${ }^{74}$ See Oberman, $85 \mathrm{~J}$ Crim L \& Criminol at 58 (cited in note 19) (discussing the overt sexualization of girls in films and fashion, legitimizing them as sexual targets and helping them become such targets).

${ }^{75}$ See Halleck, Emotional Effects of Victimization at 681-82 (cited in note 40) (discussing the histories of sexually promiscuous adolescent girls and finding that most come from disturbed homes and many were seduced by older men); id at 687-703 (concluding that sexual aggression relates to poor home environment and emotional deprivation); William N. Friedrich, Foreword, in Sharon K. Araji, ed, Sexually Aggressive Children: Coming to Understand Them xviii (Sage 1997) ("Although sexual abuse is not a universal predictor of sexual aggression in children, it is more likely to be a predictor in female children because females have fewer opportunities to behave in aggressive ways."). See also Oberman, $85 \mathrm{~J}$ Crim L \& Criminol at $35 \mathrm{n} 109$ (cited in note 19) (" $[\mathrm{T}]$ here is a reason to suspect that girls who demonstrate sexual promiscuity may in fact be survivors of childhood rape.").

${ }^{76}$ See Oberman, $85 \mathrm{~J}$ Crim L \& Criminol at 53-59 (cited in note 19) (describing the vulnerability of teenage girls: insecurity, low self-esteem, and declining academic 
order to solicit love, affection, attention, physical closeness, and validation from men. ${ }^{77}$ These girls may be unaware of the very real risks they run when they seek to fulfill their needs and affirm their self-worth through sex rather than alternative means. ${ }^{78}$ Sexually provocative behavior, therefore, may demonstrate vulnerability rather than maturity.

This analysis indicates that sexually provocative behavior is not a reliable indicator of the young female's maturity and ability to consent. Thus, using this behavior to mitigate the man's punishment introduces high decision and error costs into the selection of an appropriate punishment for male defendants. Courts have difficulty accurately deciding what a particular act means. Moreover, the vulnerable female will bear more of the risk that the decision will be wrong; some men will be punished less severely than their actual culpability suggests.

\section{B. Using Sexually Provocative Conduct as a Proxy for Lack of Coercion}

Courts have also used a young female's sexually assertive behavior as a proxy for lack of coercion. A young female's sexually provocative conduct may lead judges and juries to believe that the man did not behave culpably; that is, because she initiated the encounter, he must not have coerced her. ${ }^{79}$ However, this inference does not follow. Sexually provocative conduct is a poor proxy for lack of coercion. The fact that a young female initiated some sexual activity-such as kissing, cuddling, or fondling-does not necessarily imply that she wanted to participate in more intimate activities. Therefore, merely initiating or engaging in foreplay

achievement).

"See Halleck, Emotional Effects of Victimization at 682 (cited in note 40) ("The girls in a quest for love, warmth, nurturance or dependency learn that they can receive such gratification only through sexual expression."); Oberman, $85 \mathrm{~J}$ Crim L \& Criminol at 19 (cited in note 19) ("A multiplicity of factors induce girls to consent to sex: to feel liked or loved, to feel closer to someone, to become popular."). See also Kitrosser, 4 Va J Soc Pol \& $\mathrm{L}$ at $324-26$ (cited in note 42 ).

${ }^{78}$ See generally Thompson, Going All the Way at ch 1-3 (cited in note 15) (contrasting the "popular" and "fast-track" girls who seek fulfillment and belonging through sports, social status, and academic success with the "victims" who use sex to gain love and intimacy and are often left hurt and wounded by their sexual experiences).

${ }^{79}$ A startling example can be found in State $v$ Nice, 103 Idaho 89, 645 P2d 323, 324 (1982), where the fourteen year old victim testified that she disrobed and told the defendant that she "wanted to have sex." See also State v Rush, 24 Kan App 2d 113, 942 P2d 55, 56 (1997) (reducing defendant's sentence after victim said, " $\mathrm{I}$ 'm the one that made the moves on him that night"). 


\section{should be insufficient evidence to warrant reducing the man's punishment. ${ }^{80}$}

A defendant might nevertheless argue that his behavior is less culpable-and therefore less deserving of punishment-than that of those men who actively seek out teenage girls for sexual encounters. ${ }^{81}$ If a man responds to a young girl's advances and exploits her initial willingness by progressing to more intimate activities, however, his actions are as blameworthy as if he actively sought her out for a sexual encounter. Her initiation does not remove his responsibility for ensuring that she is not engaging in sexual activities unwillingly. ${ }^{82}$ Instead, men should be responsible for resisting the Lolitas of the world and recognizing the societal boundaries placed on their sexual gratification. ${ }^{83}$

To mitigate the punishment of men who exploit the initial willingness of their young female partners sends two socially undesirable messages. First, mitigation limits the deterrent effect of the law by decreasing the social stigma attached to having sex with underage females. This may lead men to believe that they do not need to control their urges and that they can be coercive as long as the adolescent girl "made the first move." The decreased social stigma also reinforces the notion that men have irrepressi-

${ }^{80}$ This is especially true when one considers that victim and defendant accounts of the degree of resistance or encouragement tend to differ substantially. One study found that, according to the defendants, almost 49 percent of their victims "encouraged" them and approximately 15 percent of victims resisted. In contrast, according to the official record (based primarily on the victims' accounts), about 75 percent of victims resisted the defendant and only 16 percent of victims encouraged him. MacNamara and Sagarin, Sex, Crime, and the Law at 76 (cited in note 24).

${ }^{81}$ An analogy can be drawn to the doctrine of adequate provocation in homicide: "One who kills only when a reasonable person would be governed by passion is less culpable and less dangerous than another who would kill under less provocative circumstances." Arnold H. Loewy, Culpability, Dangerousness, and Harm: Balancing the Factors on Which Our Criminal Law Is Predicated, 66 NC L Rev 283, 302 (1988). This sort of rationalization is fairly common among statutory rapists. See Slovenko, A Panoramic View at 57 (cited in note 59) (stating that adults who engage in sex with children "are generally highly inadequate and helpless, and they seek an easy explanation for their behavior; they often rationalize that they were seduced by sexually aggressive, precocious young boys or girls"). See also Timothy Egan, Contact With Young Lover Lands Ex-Teacher in Prison, NY Times A9 (Feb 7,1998 ) ("[P]eople who treat sex defendants say such people typically justify under-age sex by saying the victim is advanced emotionally.").

${ }^{82}$ Again, as in murder, the provocation may not be reasonable. See Loewy, 66 NC L Rev at 302-03 (cited in note 81) (describing the problems of determining what kind of provocation is reasonable and should be the basis for mitigation in murder cases).

${ }^{3}$ See Slovenko, A Panoramic View at 57 (cited in note 59) ("The sometimes extreme seductiveness of a young female is a factor which affects motivation, but it is a factor which, properly, has no place in the law.").

${ }^{84}$ See id at 56 ("The criminal law seeks to deter the adult male from engaging in promiscuous activity with minor females, and the burden, quite rightly, is entirely on the adult male to restrain and control himself, irrespective of the temptation."). 
ble sex drives and that women (and girls) are responsible for ensuring that they do not entice or provoke men into losing control. ${ }^{85}$

Second, mitigation may indicate that victim conduct is an appropriate basis for mercy.$^{86}$ Courts often mitigate punishment out of mercy, taking into account the particularities of a defendant's situation and story. ${ }^{87}$ The circumstances leading up to and surrounding the unfolding of a crime are a relevant part of a defendant's story. In the statutory rape context, however, courts should not consider victim conduct in the mercy calculus because doing so inappropriately intermingles the defendant's and victim's stories: he is treated less severely not because his own conduct or behavior is understandable or less blameworthy but because his victim's conduct is blameworthy. The fact that sherather than he-is the one who is judged ${ }^{88}$ reinforces the idea that society values a sexually provocative girl less than her chaste sisters. ${ }^{89}$

${ }^{35}$ See Odem, Delinquent Daughters at 68 (cited in note 8) (quoting an Alameda County, California Superior Court judge: "With a girl over the age of sixteen years and mature appearance it would be pretty hard for a man indeed to so control himself as to eliminate himself from all present danger . . . and under the circumstances it would be a pretty strong man who could escape, a pretty strong man"). See also Kitrosser, 4 Va J Soc Pol \& $\mathrm{L}$ at 292 (cited in note 42 ) (describing the belief that a woman's dress or actions can lead a man past the "point of no return").

${ }^{36}$ Under one conception, mercy is a gift to the defendant: he is punished less than he otherwise deserves because society considers his well-being out of compassion and pity. See Jeffrey G. Murphy and Jean Hampton, Forgiveness and Mercy 158-60 (Cambridge 1988). For a discussion of different constructions of the concept of mercy, see id at 162-86.

${ }^{87}$ See Dan M. Kahan and Martha C. Nussbaum, Two Conceptions of Emotion in Criminal Law, 96 Colum L Rev 269, 367-68 (1996) (analyzing the role of emotion in criminal law). Kahan and Nussbaum describe the Native Son character Bigger Thomas's deprived background as a compelling reason for mercy. Id at 370 . Other examples might include a battered woman who kills her husband after enduring years of abuse or a family member who commits a mercy killing of a terminally ill loved one.

${ }^{3}$ Courts are, however, aware of this problem. See People $v$ Roach, $129 \mathrm{Cal} 33,61 \mathrm{P}$ $574,574(1900)$ ("We must judge of the defendant's intent by his conduct, and not by that of his victim."); Alston $v$ Texas, 1991 Tex App LEXIS 2366, *7 (unpublished opinion) (declining to define the crime according to community standards regarding victim conduct); New Jersey $v$ Budis, 125 NJ 519, 593 A2d 784, 791 (1991) ("[T] he evidence may divert the jury's attention from the behavior of the defendant to that of the victim."); Ohio $v$ Tomlinson, 33 Ohio App 3d 278, 515 NE2d 963, 966 (1986) (finding that lower court did not err in preventing the defendant from questioning the nine year old rape victim about her past sexual conduct because such questioning "puts the victim on trial"). See also Susan Estrich, Rape, 95 Yale L J 1087, 1094 (1986) (discussing how the law of forcible rape focuses on the victim's conduct as much as or instead of on the defendant's conduct and stating that the issue in rape is "the appropriateness of the woman's behavior, according to male standards of appropriate female behavior").

- See Oberman, $85 \mathrm{~J}$ Crim L \& Criminol at 37 (cited in note 19) (discussing the Buttafuoco case as an example of how "the law traditionally has protected only those minor girls who are deemed to require or merit protection-i.e., the 'good' girls"). 
Less controversially, in both Cases 3 and 4 (a coercive male and a mature young female or an immature young female), mitigating the man's punishment based on the female's sexually provocative conduct inappropriately focuses attention on the propriety of her conduct rather than the culpability of his.

\section{RESisting THe PRESSURE TO Mitigate}

Statutory rape, like bigamy and adultery, is a classic "morality offense" and therefore fits neatly into one of the traditional categories for strict liability. ${ }^{90}$ Morality offenses are in essence crimes against community mores and moral standards. ${ }^{91}$ Community morality in the statutory rape context dictates that older, adult men have no morally sound reason to be sexually involved with adolescent girls-particularly outside of marriage. ${ }^{92}$

Statutory rape, however, is more than a mere morals offense. Unlike bigamy and adultery, it provides needed protection for vulnerable members of society-adolescent girls. Historically, proving rape has been a very difficult task, as women had to demonstrate that their assailants (physically) forced them to have sex. ${ }^{93}$ Eliminating the force requirement when the rape was committed against a female under the age of consent enabled the criminal justice system to convict her assailant more easily, ${ }^{94}$ protecting both her and young women as a class. ${ }^{95}$ It also protected young women from consenting to sex without understanding the risks involved.

As with other strict liability crimes, the severity of the punishment combined with its strict liability nature create community pressure on courts to find some "breathing room" in the law-to inject some flexibility into the seemingly inflexible regime. ${ }^{96}$ Some flexibility is required, because statutory rape covers

${ }^{20}$ See Levenson, 78 Cornell L Rev at 418 (cited in note 7).

${ }^{21}$ See id at 422-23.

${ }^{22}$ See People $v$ Hernandez, 61 Cal 2d 529, 393 P2d 673, 674 (1964) (stating that statutory rape laws are motivated by a "popular conception of the social, moral, and personal values which are preserved by the abstinence from sexual indulgence on the part of young women"). See also McBrayer v Mississippi, 467 S2d 647, 648 (Miss 1985) (stating that "[f]orty-six year old men have no business engaging in sexual relationships with thirteen year old girls in any context").

${ }^{93}$ See Estrich, 95 Yale L J at 1105-06 (cited in note 88).

' See Larson, 9 Yale J L \& Human at 11, 15, 20-21 (cited in note 36).

${ }^{95}$ See Odem, Delinquent Daughters at 8-9 (cited in note 8).

${ }^{\circ}$ Statutory rape is not the only strict liability offense where courts have tried to "bring the strict liability doctrine in line with common notions of moral culpability." Levenson, 78 Cornell $L$ Rev at 428 (cited in note 7). To do so, courts have reinterpreted statutes, attacked the actus reus and causation requirements, relied on prosecutorial discretion, and imposed minimal punishment. Id at 428-35. In the statutory rape context, the 
a broad range of acts: the brutal, violent rape of a nine year old; a daughter's continued sexual abuse by her father; and the consensual sexual relationship between a fifteen year old girl and her twenty year old boyfriend. Courts introduce flexibility into the law of statutory rape by modulating punishment according to the perceived culpability of the statutory rapist, ${ }^{97}$ allowing them to enforce society's moral condemnation of the behavior while ensuring that the least culpable individuals do not receive excessive punishment.

As explained in Part I, most states have abandoned simple statutory schemes that set a single age of consent and criminalize all sexual intercourse with girls below that age. The newer, graduated age of consent statutes decrease the pressure to mitigate men's punishment based on their victims' conduct. ${ }^{98}$ Graduated schemes, however, do not completely eradicate courts' desire to mitigate. Under these schemes, defendants still are (for the most part) strictly liable if they engage in prohibited conduct. ${ }^{99} \mathrm{~A}$ particular segment of a graduated scheme may treat a wide range of culpable behavior similarly. In Connecticut, for example, a twenty year old man who has consensual sex with his fifteen year old girlfriend may suffer the same punishment as a thirty-five year old man who coerces a fourteen year old neighbor into having sex. ${ }^{100}$

public and courts have expressed concern that the inflexible application of the law could unjustly punish a man whose actual guilt is slight. See Mueller, Sexual Conduct and the Law at $\mathbf{5 5}$ (cited in note 31) (noting that the punishment for statutory rape is severe although "the actual guilt of the perpetrator may be but slight").

"See Suro, Town faults law, Wash Post at A1 (cited in note 12) (describing a Connecticut town's frustration with the inflexible application of a statutory rape law to consensual intercourse between an eighteen year old man and his fifteen year old girlfriend).

* See Part I.A.

Many state statutes explicitly state that mistake of age is no defense. See, for example, 11 Del Code Ann $\S 762$ (a) (Michie 1974); ND Cent Code $\S 12.1-20-01$ (Michie 1997) (providing that there is no mistake defense where criminality depends on the child being under fifteen years old); Utah Code Ann \& 76-2-304.5 (Supp 1997). Others, however, provide for a mistake of age defense in their statutes. See, for example, Alaska Stat $\$ 11.41 .445$ (Michie 1996) (providing that if the victim is younger than thirteen, there is no mistake defense; but if the victim is over thirteen, a reasonable mistake defense is permitted); Mont Code Ann $\S 45-5-511$ (1997) (making mistake defense available if victim is at least fourteen years old; no defense if victim is less than fourteen); Ark Stat Ann § 5-14102 (Michie 1997) (same); MPC $\S 213.6$ (making mistake defense available for sexual intercourse with a minor under age sixteen). A few courts have recognized this defense. See, for example, Hernandez, $393 \mathrm{P} 2 \mathrm{~d}$ at 678. However, few others have followed. See Phipps, 22 Seton Hall Legis J at 51-52 \& n 219 (cited in note 5). By establishing a mistake of age defense, state legislatures may be permitting defendants to introduce indirectly evidence that the victim was sexually provocative or aggressive, along the lines of "she acted like she was sixteen." In cases where the victim is the sexual aggressor, the man could possibly avoid conviction.

${ }^{100}$ Conn Gen Stat Ann $\S \S 53 a-71,53 a-35 a$ (West 1994) (providing that both defendants 
As a consequence, even under graduated statutes, judges may try to distinguish between defendants by mitigating the punishment of the defendant whose behavior they deem to be less dangerous or culpable. Unfortunately, judges may use the victim's conduct as one factor in making these determinations. ${ }^{101}$ Therefore, despite these legislative developments, it remains necessary to consider whether mitigation based on victim conduct is appropriate.

As explained above, mitigation based on victim conduct raises two concerns. First, because initiating sexual activity is an imperfect proxy for lack of coercion, courts should not rely on it to evaluate whether the male coerced his younger partner at some stage of their sexual relations. Second, using the victim's sexual aggression to mitigate a defendant's punishment distinguishes defendants not according to their actions but according to those of their victims. ${ }^{102}$

For these reasons, courts should not reduce statutory rapists' punishment based on their victim's sexually provocative acts. A more satisfactory alternative would be for legislatures to lower the presumptive punishment for statutory rape to a fairly minimal level, such as imprisonment for one year.

To classify statutory rapists according to their relative dangerousness and culpability, legislatures should specify aggravating factors that courts can use to increase punishment. For example: (1) whether the defendant physically coerced or psychologically manipulated the victim to have sex; (2) whether the defendant was more than ten years older than the victim; (3) whether the defendant was a member of the victim's family; and (4) whether the defendant had committed other sex offenses. Ab-

would be guilty of sexual assault in the second degree, a Class $\mathbf{C}$ felony subject to a punishment of one to ten years imprisonment). See also Ala Code §§ 13A-6-62(a)(1), 13A-5-6 (Michie 1975 \& Supp 1997) (providing that both defendants would be guilty of rape in the second degree, facing sentences of two to twenty years imprisonment).

${ }^{101}$ Some states do this explicitly in their sentencing guidelines. See, for example, Ark Stat Ann \& 16-90-804(d)(1)(A) (Michie 1987 \& Supp 1997) (including that "the victim played an aggressive role in the incident or provoked or willingly participated in it" as a mitigating factor); Wash Rev Code Ann § 9.94A.390(1)(a) (West 1988) (providing that mitigating circumstances include the fact that "[t]o a significant degree, the victim was an initiator, willing participant, aggressor, or provoker of the incident"). For an application of such a departure to statutory rape, see State $v$ Rush, 24 Kan App 2d 113, 942 P2d 55, 57 (1997) (applying Kan Stat Ann \$ 21-4716(b)(1)(a)).

${ }^{102}$ See Alston, 1991 Tex App LEXIS 2366 at *7. Victim conduct plays a role in various areas of law, including homicide (manslaughter and adequate provocation) and torts (comparative or contributory negligence). Victim conduct should not be considered in the statutory rape context, however, because the victims are young girls that society, through legislation, has decided to protect. This decision is thwarted when the victim's conduct is the measure of the man's culpability. 
sent such aggravating factors, the defendant would receive the presumptive punishment-the victim's conduct would be excluded from the court's sentencing decision. ${ }^{103}$ By asking the question based on the defendant's behavior (did he physically coerce his young partner?), rather than the female's behavior (did she behave provocatively to initiate the encounter?), the law would judge the defendant's behavior-not the female's. Starting with a low baseline punishment and working up unequivocally expresses contempt for the defendant's actions. Starting with a higher level of punishment and reducing, as courts do now, risks sending a mixed message: what the defendant did was bad but it should be excused (or was understandable and thus less culpable) because the girl herself acted badly. ${ }^{104}$

This proposal would also decrease community pressure on the courts to mitigate statutory rapists' punishment, because it reduces the possibility of an unduly harsh sentence. A man whose actions fall within the least culpable category (for example, the eighteen year old who had consensual sex with his fifteen year old neighbor) ${ }^{105}$ would not risk being subjected to a presumptive punishment inconsistent with his culpability. In contrast, a man whose conduct is most egregious would receive a higher punishment to reflect the culpability of his acts. ${ }^{106}$

This proposal effectively addresses the two problems posed by mitigation of punishment based on victim conduct. First, by removing victim conduct from a court's consideration, the proposal correctly places more of the burden of risk and error on the male defendant. The male defendant should bear more of this burden because the benefits that he may gain (sexual pleasure) are outweighed by the potentially high costs inflicted on his female partner (pregnancy, STDs, emotional difficulties). ${ }^{107}$ Because

${ }^{103}$ This argument assumes that none of the aggravating factors concern victim conduct. In defining aggravating factors, states would need to take care that they do not reintroduce considerations of victim conduct.

${ }^{104} \mathrm{~A}$ low presumptive sentence probably would not impact the overall deterrent effect of the law because being convicted of a sex offense creates significant reputational costs that will deter many men from engaging in sex with underage females. See Levenson, 78 Cornell L Rev at 434-35 (cited in note 7).

${ }^{105}$ See Suro, Town faults law, Wash Post at A1 (cited in note 12); Rosemary P. McNicholes, Teen Sex: It's A Crime-But Should It Be?, Conn Law Trib 2 (Aug 10, 1992).

${ }^{108}$ See Louise Kierman, The criminal charge; 'statutory rape' law gets murkier with age, Chi Trib IN (July 28, 1995) (describing the conduct of Mel Reynolds, a former Illinois Congressman, as "the statutory rape scenario at its most extreme: a much older, elected official accused of initiating a sexual relationship with a high school student and using his influence and money to foster it").

${ }^{107}$ This is similar to the debate over whether "no means no" in forcible rape cases. Men and women act as though "no" means "maybe" or "keep trying" in some circumstances and "no" in others. This social custom leaves both men and women vulnerable to errors and the 
the man cannot rely on his underaged partner's conduct-real or perceived-to exculpate him, mandating a definite (albeit low level) punishment for all defendants ensures that all girls receive the same basic protection from the law, regardless of their actions.

Second, and more importantly, this proposal would send less ambiguous messages about the victim's and defendant's relative worth. Increasing rather than reducing the man's punishment would properly focus on the man's conduct instead of the young female's. Therefore, there would be less risk that the law would devalue or blame the victim because of her conduct.

\section{CONCLUSION}

Statutory rape laws are designed to protect adolescent girls from being sexually exploited, either because of their own lack of experience or the coercive behavior of adult men. In an attempt to protect girls and avoid difficult inquiries into a particular girl's actual stage of emotional and physical development, the legal system has opted for a strict liability regime that protects all girls below a certain age. This system, however, has the potential of treating all adult defendants in the same manner-irrespective of their actual culpability. Coupled with potentially severe punishments, this "one-size-fits-all" system exposes courts to pressure to distinguish between defendants and decrease the punishment of those whom they deem to be less culpable.

One way to distinguish defendants and determine their relative culpability has been to use evidence of the victim's sexually provocative behavior for sentencing purposes. A teenage girl's sexually provocative behavior, however, is an imprecise proxy for either emotional maturity or lack of coercion. As a result, mitigating a man's punishment based on the victim's conduct incorrectly shifts the burden of error onto teenage girls. Furthermore, mitigation inappropriately emphasizes the girl's conduct rather than her older male partner's actions.

To avoid these problems, courts should not rely on a teenage girl's behavior when determining the level of punishment appropriate for her older male partner. Instead, legislatures should lower the presumptive level of punishment for statutory rape.

associated costs. If the man ignores a woman's "no," he risks committing forcible rape; if instead he heeds it, he may lose a sexual opportunity. The women who coyly hide behind "no" when they mean "yes" put those women for whom "no" means "no" at risk, because the sincere woman's resistance may be misinterpreted as encouragement. For an argument that the burden of risk should be placed on the man to determine if his partner's "no" means "no," see Estrich, 95 Yale L J at 1104-05 (cited in note 88). 
Courts should then use aggravating factors based entirely on the man's actions to increase the sentence when necessary to fashion an appropriate punishment. 


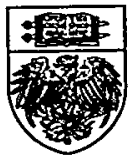

